\title{
Tysk-italiensk alliance kan drive EU fremad
}

Af Ole Bang Nielsen i Bruxelles

EU kan i de kommende 12 måneder tage vigtige skridt mod bankunionen, en mere vækst-orienteret økonomisk politik og muligvis også en ændring af EU-traktaten, hvis Italiens unge, dynamiske regeringschef Matteo Renzi kan finde sammen med forbundskansler Angela Merkel.

Er EU endt som 'en kedelig gammel tante', der kun kan revse og ryste på hovedet af enhver nytænkning?

Det var i hvert fald det spørgsmål, som Italiens frejdige socialdemokratiske regeringschef Matteo Renzi - der selv er på den 'rigtige' side af 40 - stillede, da han fremlagde det nuværende italienske EU-formandskabs program for Europa-Parlamentet.

Men uanset om det kommer til at foregå tanteagtigt eller ej, så vil der i det kommende år frem til sommeren 2015 skulle træffes store beslutninger i det europæiske samarbejde. Der synes for første gang siden udbruddet af finans- og eurokrisen en chance for, at Europas politikere kan kigge ud over den nationale tallerkenrand og de øjeblikkelige økonomiske problemer.

De seneste måneder i Bruxelles har naturligt nok været præget af konflikten med Rusland om Ukraines fremtid og processen med at få sat navne på EU's topposter.

Men der er tre andre vigtige spørgsmål, der presser sig på, når EU's nye ledelse i efteråret tager fat på arbejdet:

\section{Bankunionen}

EU's bankunion skal træde i kraft. Det er den største udvikling af eurosamarbejdet siden dets begyndelse i 1999. Forhåbningen er, at man med en effektivt fungerende bankunion på plads kan forhindre en gentagelse af finanskrisen - eller i det mindste mindske dens følger så meget, at den ikke kan true eurosamarbejdet.

Metoden bliver at oprette et fælles banktilsyn placeret under den Europæiske Centralbank, ECB, i Frankfurt, som skal overtage kontrollen og tilsynet med de største banker i Europa fra de nationale myndigheder. Samtidig får EU retten til at lukke banker eller bestemme, om de skal have

Ole Bang Nielsen har arbejdet som journalist i Bruxelles siden 1990 og har skrevet for blandt andre Berlingske Tidende og Dagbladet Information. 


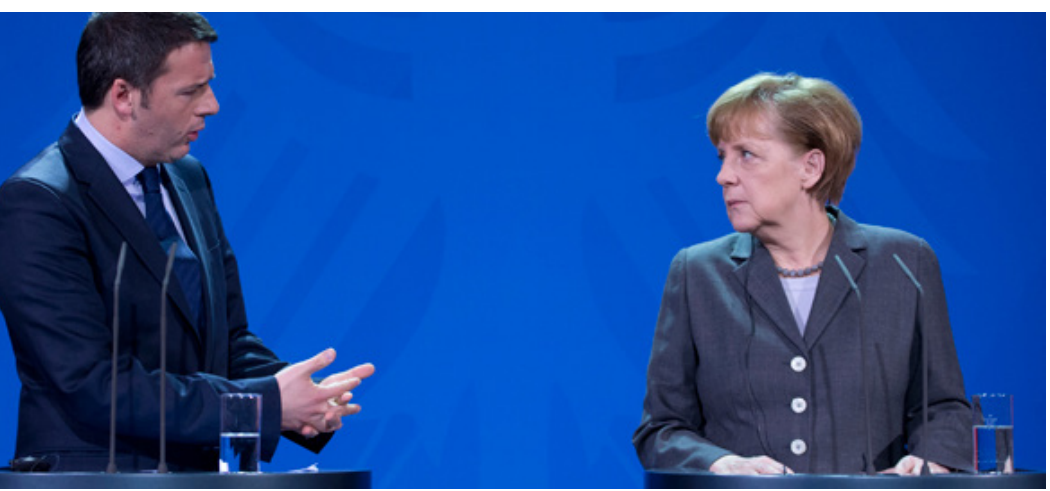

støtte, hvis de kommer i problemer. Og endelig skal der oprettes en fælles fond finansieret af indskud fra bank- og finanssektoren til kommende redningsaktioner.

Målet er at bryde den onde cirkel, hvor skatteydernes penge er blevet brugt til at redde banker i problemer i de seneste år. Hvilket igen har skabt problemer for statsfinanserne og for en række landes muligheder for at forblive i eurosamarbejdet. 600 mia. euro har EU's skatteydere under finanskrisen pumpet ind i bankerne - svarende til seks gange EU's årlige budget.

Med bankunionen får EU den samme indflydelse på bank- og finanssektoren, som man i mere end 20 år har haft over industrien gennem det indre marked. Så overgangen til bankunionen er ikke blot et spørgsmål om finansielle regler, men også om at medlemslandene overgiver betydelig suverænitet til det fælles EU-system.

Den danske regering har endnu ikke meldt officielt ud om, hvorvidt den vil koble sig på bankunionen, der i første omgang omfatter de 19 lande, der er med i euro-zonen. Men det betragtes som en selvfølge. Nationalbanken har i hvert fald gjort det klart, at den forudser problemer for den danske banksektor og muligvis også landets pengepolitik, hvis Danmark står udenfor. "Det er Nationalbankens opfattelse, at et medlemskab er i dansk interesse," sagde Nationalbankens direktør Lars Rohde tidligere i år. Og man skal vist tilbage til 1970’erne for sidst at finde en dansk regering, der overhørte Nationalbankens advarsler.

Hovedparten af de ni EU-lande uden for euroen ventes da også gå med i bankunionen med Storbritannien som en væsentlig undtagelse.

\section{Gang i økonomien}

Men bankunionen i sig selv løser ikke Europas dybere økonomiske problemer med lav vækst og 25 millioner arbejdsløse. Et studie fra EU-Kommissionen viser, at ingen af de europæiske lande vil være at finde blandt verdens otte største økonomier i 2050, hvis den europæiske vækstrate ikke øges. Det er det andet vigtige spørgsmål på dagsordenen i det kommende år. Hvordan får man virkelig gang i de økonomiske hjul uden at undergrave den finanspolitiske stabilitet, der er en forudsætning for eurosamarbejdet?

Den Europæiske Centralbanks chef, Mario Draghi, har på sine italienske skuldre nærmest båret Europa ud af eurokrisen. Først gennem sin udtalelse i september 2012, hvor han forsikrede, at ECB vil gøre alt og bruge alle midler for at redde euro-samarbejdet, hvilket standsede markedets spekulationer mod de svageste lande i eurozonen. Derpå har han gennem en dristig pengepolitik, der har bragt renten ned på historisk usete 0,15 pct, holdt gang i den svage økonomiske vækst. 
Men EU's økonomi har desperat brug for nye investeringer, og at forbrugerne genvinder tilliden til økonomien.

Den nye stjerne på venstre side i europæisk politik, premierminister Matteo Renzi, har givet sit bud. Han var den eneste af de store EU-landes ledere, hvis parti kunne notere sig for succes ved valget til EuropaParlamentet i maj. Han sprudler af selvtillid og forsøger nu at dreje EU's økonomiske politik i en noget andet retning.

Hans udtalelser til Europa-Parlamentet om EU's 'tantede' opførsel var netop rettet mod en for nidkær fortolkning af de økonomiske regler - EU's stabilitetspagt og den nye finanspagt - der pålægger medlemslandene at føre en stram finanspolitik.

Renzi kræver med støtte fra sin socialistiske partifælle, præsident François Hollande i Frankrig, at der gennemføres et stort europæisk investeringsprogram. Og ikke mindst, at Europa-Kommissionen anlægger en mere fleksibel fortolkning af reglerne for euro-samarbejdet; herunder at midler investeret i ny vækst ikke skal regnes med i de statslige balancer som et underskud.

Det skulle ifølge den politiske lærebog umiddelbart føre til en konfrontation med Tysklands magtfulde kansler Angela Merkel på linje med opgøret mellem Merkel og den nyvalgte Hollande tilbage i 2012 .

Den 39-årige Renzi og hans venstrefløjs-koalition er imidlertid en anden politisk størrelse end Hollandes franske socialister. Renzi betragtes i Bruxelles som mere åben over for reformer og har bebudet et nyt program herom. Men det kræver, at Europa-Kommissionen vender det blinde øje til, at Italiens gæld en overgang vil stige. Og Italien har efter Grækenland den næsthøjeste offentlige gæld med 135 procent af bruttonationalproduktet, BNP.

Renzi ønsker simpelthen, at EU holder sig væk fra hans græsplæne med formaninger og advarsler, mens han forsøger at skabe opbrud i den fastlåste italienske økonomi.

Europa-Kommissionens kommende for- mand, den luxembourgske kristendemokrat Jean-Claude Juncker, kan være parat til at give italienerne og de andre svage euro-ande en længere snor, vurderes det i Bruxelles. Det samme gælder faktisk forbundskansler Merkel, selv om hun er under pres fra sit konservative bagland og den tyske Forbundsbank.

"Merkel og Tyskland har en klar interesse $i$, at Renzi kommer igennem med sine reformer", siger økonomen Guntram Wolff fra det anerkendte politiske forskningsinstitut Bruegel i Bruxelles. Det vil nemlig også anspore Frankrig til at gennemføre de økonomiske reformer, som både EU og Tyskland råber efter, påpeger han.

\section{Traktatændring}

Med udsigt til, at Renzi bliver siddende som Italiens leder i en længere årrække på grund af den italienske højrefløjs splittelse og svaghed oven på Silvio Berlusconis mange skandaler, kan Tyskland og Italien komme til at udgøre et nyt makkerpar i europæisk politik, hedder det i Bruxelles. Her taler man allerede om 'Merkenzi-alliancen'.

For på et afgørende punkt har Tyskland og Italien stærkt sammenfaldende interesser, og det gælder det tredje punkt på dagsordenen i det kommende år. Nemlig, om der skal sættes gang i en ændring af EUtraktaten. Den første, siden den nuværende Lissabon-traktat blev forhandlet på plads i den portugisiske hovedstad i 2007.

Matteo Renzi har bebudet, at der skal nedsættes en ekspertgruppe, der skal se på behovet for en ændring af EU's institutionelle system, og hvordan EU i det hele taget fungerer. Det bliver taget med et gran salt i en række andre lande, hvor der ikke er megen appetit på en ny langvarig institutionel debat.

Men i Tyskland har Renzi en mulig allieret, fordi spørgsmålet om en ændring af EU-traktaten hele tiden dukker op i den tyske debat på grund af den afgørende rolle, 
som den tyske forfatningsdomstol i Karlsruhe spiller. Den tyske forfatningsdomstol kan bedst sammenlignes med den amerikanske højesteret. Den vogter nidkært over, om den tyske forfatning bliver overholdt herunder også om Tysklands indtræden i nye samarbejdsformer som finanspagten og bankunionen kan accepteres.

Det giver den tyske regering en rent praktisk politisk interesse i at få så meget som muligt traktatfæstet.

Derudover har Italien og Tyskland også en historisk fælles interesse i at få EU-samarbejdet udbygget så vidt som muligt. De to lande har tidligere taget vigtige fælles initiativer som den såkaldte ColomboGenscher aftale udarbejdet af de to landes udenrigsministre i 1980'erne, som senere dannede grundlag for en betydelig del af samarbejdet i den politiske union, der blev forhandlet på plads i Maastricht i 1992.

I modsætning til holdningen i fx Frankrig og Danmark er tysk og italiensk politik fortsat domineret af ønsket om, at EU skal arbejde i en føderalistisk retning; altså hen mod at blive en europæisk forbundsstat. Med en erklæret føderalist som JeanClaude Juncker på EU's toppost som kommissionsformand er der for første gang i mange år skabt mulighed for at åbne en ny grundlæggende debat om EU's fremtid.

\section{Den store ubekendte}

Mod ideen om at indlede nye traktatforhandlinger taler den i øjeblikket ubekendte størrelse i europæisk politik; nemlig om Storbritannien agter at forblive i samarbejdet. Hvis EU begynder på at tale om en yderligere uddybning af samarbejdet, frygter en del diplomater i Bruxelles - bl.a. fra de nordiske lande - at det vil være vand på møllen for de politiske kræfter i London, der ønsker et fuldstændigt brud med EU.

Storbritanniens tilhørsforhold til EU skal ifølge den konservativt ledede regering i London først afgøres ved en folkeafstemning i 2017. Den britiske premierminister David
Camerons plan er at vinde det parlamentsvalg, der senest skal afholdes i maj næste år, og derpå forsøge at presse EU-partnerne til at skrue en del af samarbejdet tilbage, så nationalstaterne igen får mere magt.

Derpå vil han i folkeafstemningen i 2017 plædere for, at Storbritannien forbliver i EU, selv om mange af hans partifæller ønsker en egentlig udtræden af EU.

Problemet er blot, at stort set ingen af de øvrige EU-lande deler Camerons ønsker. Topmødet i juli, da Cameron blev stemt ned af de øvrige EU-lande på spørgsmålet om udnævnelsen af Jean-Claude Juncker som kommissionsformand, viste graden af britisk isolation. Kun Ungarns højre-nationalistiske regeringschef Viktor Orban, der i forvejen er lagt på is i EU-politik, støttede Camerons modstand mod Juncker.

Det var kun kulminationen på en række frustrerende år for forholdet mellem Storbritannien og EU-partnerne på 'kontinentet'. Storbritannien isolerede sig også fuldstændigt i forhandlingerne om finanspagten i 2011-2012, hvor London tidligt meldte fra - og nu sammen med Tjekkiet er det eneste land, som ikke deltager. Det samme gjaldt forhandlingerne om bankunionen, hvor regeringen i London har gjort det klart, at den ikke vil deltage.

Storbritanniens resterende venner på kontinentet vrider hænder. Lande som Sverige, Danmark og Holland har i perioder forsøgt at slå bro mellem London og de store eurolande, men uden held.

Den tyske forbundskansler Merkel har gjort det samme gennem et personligt diplomati over for Cameron, men er gået skuffet bort. Især efter episoden med Juncker, hvor hun måtte støtte udpegelsen af sin luxembourgske kristen-demokratiske partifælle, som i øvrigt også er kendt og populær i den tyske offentlighed. "Briterne må lære at forstå, at de ikke er de eneste, som har en indenrigspolitisk dagsorden og debat", som en højtstående diplomat i Bruxelles udtrykker det. 
Umiddelbart kunne man håbe på en borgfred om det 'britiske problem', som det nu kaldes i Bruxelles, frem til parlamentsvalget i maj 2015. Men der kan hurtigt komme nye hår i suppen. For eksempel i tilfælde af, at Cameron vælger at fremskynde valget.

Selv om man i London stadig betragter sig som en international magt, er det svært at se, at de øvrige EU-lande vil strække sig langt for at beholde Storbritannien om bord. Hvis der kommer en ny traktatrunde vil man i hvert fald ikke være parat til at imødekomme Camerons krav om en tilbagerulning af EU's magt på andet end det rent symbolske plan.

"Merkel har mange prioriteter i sin Europa-politik. Kun en af dem er at bevare David Cameron om bord", som en af de mest erfarne britiske EU-kendere, Charles Grant, direktør for Centre for European Reform udtrykker det.

Frankrig og Italien vejer tungere for Tyskland, fordi de er euro-partnerne, og Polen presser sig på for både at komme med i euroen og spille en vigtigere sikkerheds- og udenrigspolitiske rolle, og det må man tage hensyn til i Berlin, påpeger han.

\section{Parti-polarisering}

Den vigtigste udvikling i EU-samarbejdet i øjeblikket er netop den parti-politisering af samarbejdet, der foregår. Valget til Europa-Parlamentet viste, at der på tværs af grænserne er ved at etablere sig egentlige politiske 'europæiske' partier, hvilket også resulterede i den proces, hvor Europa-Parlamentet pegede på Jean-Claude Juncker som dets forslag til formand for Europa-Kommissionen, hvilket medlemslandene så accepterede.

"For første gang har vi haft et Europavalg, som halvvejs fortjener denne betegnelse", sagde den 85-årige tyske filosof Jürgen Habermas til Frankfurter Allgemeine Zeitung efter valget til Europa-Parlamentet. Han har ellers ofte kritiseret EU for at være et for teknokratisk projekt.

"Fremgangen for højre-populisterne ved valget tvang de førende politiske partier til at tage borgernes utilfredshed alvorligt. Vi befinder os nu midt i en åben politisk udvikling, hvor de store politiske partier må bekende sig til det europæiske samarbejde".

Europa-Parlamentets voksende indflydelse efter udnævnelsen af Juncker vil komme til at spille ind på en række sager $\mathrm{i}$ det kommende år:

Muligheden for, at EU kan indgå en hurtig frihandelsaftale med USA er skrumpet ind $\mathrm{i}$ takt med de stadig flere afsløringer af den amerikanske efterretningstjeneste NSA's aflytningsvirksomhed i Europa. Europa-Parlamentet har ført an i kampen for større datasikkerhed for EU's borgere, og det synes nu utænkeligt, at EU-parlamentarikerne vil godkende en frihandelsaftale uden større amerikanske garantier for, at NSA hegnes ind, og at europæiske standarder for datasikkerhed bliver normen.

Samtidig vil Europa-Parlamentet forlange at blive hørt i en mulig kommende debat om Europas fremtid. Modellen om i en kommende traktatændring at nedsætte et bredt sammensat konvent mage til det, der i årene 2002-2003 udarbejdede det omfattende forslag til EU's første forfatning, nyder stor opbakning i Europa-Parlamentet. 